\title{
Development of a Simple Spheroid Production Method Using Fluoropolymers with Reduced Chemical and Physical Damage
}

\author{
Hidetaka Togo $^{1}$ D, Kento Yoshikawa-Terada ${ }^{2}$, Yudai Hirose ${ }^{1}$, Hideo Nakagawa ${ }^{1}$, Hiroki Takeuchi ${ }^{2, *(D)}$ \\ and Masanobu Kusunoki ${ }^{1, *}$ \\ 1 Graduate School of Biology-Oriented Science and Technology, Kindai University, 930 Nishimitani, \\ Kinokawa 649-6493, Wakayama, Japan; 1944730001m@waka.kindai.ac.jp (H.T.); \\ 2133730002c@waka.kindai.ac.jp (Y.H.); nakagawa@waka.kindai.ac.jp (H.N.) \\ 2 Department of Obstetrics and Gynecology, Mie University Graduate School of Medicine, 2-174 Edobashi, \\ Tsu 514-8507, Mie, Japan; yoshikawa-k@med.mie-u.ac.jp \\ * Correspondence: h-takeuchi@med.mie-u.ac.jp (H.T.); kusunoki@waka.kindai.ac.jp (M.K.); \\ Tel.: +81-59-232-1111 (H.T.); +81-736-77-3888 (M.K.)
}

check for updates

Citation: Togo, H.; Yoshikawa-Terada, K.; Hirose, Y.; Nakagawa, H.; Takeuchi, H.; Kusunoki, M. Development of a Simple Spheroid Production Method Using Fluoropolymers with Reduced Chemical and Physical Damage. Appl. Sci. 2021, 11, 10495. https://doi.org/ 10.3390/app112110495

Academic Editor: Francisco Arrebola

Received: 19 September 2021

Accepted: 4 November 2021

Published: 8 November 2021

Publisher's Note: MDPI stays neutral with regard to jurisdictional claims in published maps and institutional affiliations.

Copyright: (c) 2021 by the authors. Licensee MDPI, Basel, Switzerland. This article is an open access article distributed under the terms and conditions of the Creative Commons Attribution (CC BY) license (https:// creativecommons.org/licenses/by/ $4.0 /)$.

\begin{abstract}
Establishing an in vitro-based cell culture system that can realistically simulate in vivo cell dynamics is desirable. It is thus necessary to develop a method for producing a large amount of cell aggregates (i.e., spheroids) that are uniform in size and quality. Various methods have been proposed for the preparation of spheroids; however, none of them satisfy all requirements, such as cost, size uniformity, and throughput. Herein, we successfully developed a new cell culture method by combining fluoropolymers and dot patterned extracellular matrix substrates to achieve size-controlled spheroids. First, the spheroids were spontaneously formed by culturing them twodimensionally, after which the cells were detached with a weak liquid flow and cultured in suspension without enzyme treatment. Stable quality spheroids were easily produced, and it is expected that the introduction and running costs of the technique will be low; therefore, this method shows potential for application in the field of regenerative medicine.
\end{abstract}

Keywords: spheroid; organoid; van der Waals force; fluoropolymers; adhesion; microstamp

\section{Introduction}

Cell culture, an important technique in basic and preclinical research, is a cost-effective way of reducing the number of experimental animals during the drug discovery process [1]. Although two-dimensional (2D) cell culture is a universal and valuable method, it has its limitations [2]; for example, the cells proliferate and grow in a single layer and thus lack the cell-cell and extracellular matrix (ECM) interactions present in native tissues and cells. In addition, the cells are stretched and undergo a cytoskeletal rearrangement, acquiring artificial polarity and expressing abnormal genes and proteins [3]. Unlike tissues in an in vivo environment, 2D systems cannot provide a complex and dynamic microenvironment for cells, leading to potentially invalid findings $[4,5]$. For these reasons, the majority of compounds discovered in 2D cell culture during drug discovery fail in clinical trials [6]. Therefore, it is important to establish an in vitro cell culture system that can more realistically simulate the dynamics of cells in vivo.

Three-dimensional (3D) culture systems are an excellent in vitro model that can mimic in vivo processes, such as embryogenesis, morphogenesis, and organogenesis [7]. Spheroids and organoids are cellular aggregates with complex cell-cell adhesion that generate gradients of nutrients, gases, growth factors, and signaling factors. These structures can replicate the cellular microenvironment observed in real tissues and simulate in vivo cell dynamics more realistically. Human induced pluripotent stem cells (iPSCs), the discovery of which has helped stem cell research make great strides, can be used to generate spheroids and organoids, which were employed in the elucidation of pathological conditions [8-12] 
and drug discovery [8,13-15]. Recently, organoids derived from iPSCs generated from patients with intractable diseases were used to elucidate the disease mechanisms $[16,17]$. In the field of drug discovery, the validation of drug efficacy using organoids derived from human iPSCs in the early stage of in vitro testing is expected to reduce the possibility of candidate compound failure before initiating clinical trials. Indeed, drug testing using iPSC-derived organoids has shown comparable results to those of drugs already used for treatment [18]. Because the use of spheroids and organoids is expected to increase in the future, developing methods for their efficient production is important.

Various 3D culture methods have been tried and implemented. Conventional 3D culture methods can be broadly classified into four types: micropatterned forced flotation, hanging drop, swirling culture or spinner flask, and force-driven methods [19]. The micropatterned forced flotation method involves well plates in which cells deposited inside the microwells adhere to each other in three dimensions [20-22], as well as low-adhesion plates in which areas with different cell adhesion properties are patterned to prevent cell aggregation [23]. Microfluidic systems are a type of micropatterned forced flotation that combines both the target cells and matrix components to create spheroids on microfluidic chips with microgel beads $[24,25]$. The hanging drop method utilizes the surface tension of the culture medium to form droplets, while the interface with the air is used as a microwell [26-28]. The spinner flask or swirling culture (bioreactor) is a method of spheroidization via collision and contact between cells through continuous swirling and agitation of the culture medium in which cells are dispersed $[29,30]$; this method also includes microfluidic types on a smaller scale [31-33]. Force-driven methods include magnetic methods where nanoparticles, such as iron oxide, gold, and poly-L-lysine, are attached to the cell surface. Spheroids are formed via the following: magnetic forces [34]; electric methods in which an external force, such as an electric field, is applied [35]; and acoustic tweezers [36]. Other methods have also been developed in recent years; for example, 3D printing can artificially create 3D shapes [37-39], using a computer-controlled arrangement of heterogeneous cells with a gel-like culture medium as the filler. Although these methods exhibit excellent features, such as dimensional control of the spheroid, reduction in damage and irritation to the cells, simplicity of the procedure, high success rate, mass production, high throughput, and low cost, none of them satisfy all these requirements simultaneously. A new type of classification is microfluidic devices. Microfluidic devices are devices that have microscopic grooves or tubes within. These are used for various applications, such as forming small bioreactors [32,40] or circulatory systems [31] to recapitulate in vivo, using flow paths. Some of these microfluidic methods are included in the micropatterned forced flotation method.

Fluoropolymers have a low surface free energy and are generally regarded as materials that do not allow cell adhesion. They have a high biocompatibility and inertness, due to these properties. Therefore, fluoropolymers are used in artificial blood vessels and other components that are implanted in the body. In general environments, these polymers are very stable, due to the high binding energy of $\mathrm{C}-\mathrm{F}$ bonds, and they are, thus, a safe and non-toxic material for use in the living body. However, their high inertness prevents cell adhesion, which is a problem for biomaterials. As a result, various surface modifications have been investigated to take advantage of their high biocompatibility and inert properties [41-46]. To improve adhesion, plasma treatment [47-51], UV irradiation [52-55], $\gamma$-radiation [56,57], ion introduction [58-61], and polydopamine treatment [62-66] have been employed for surface modification; however, most of these methods require high energy to break the strong $\mathrm{C}-\mathrm{F}$ bonds and add functional groups to improve adhesion.

We are working on the control of cell adhesion by manipulating the surface properties of fluoropolymers for 3D cell patterning and have found that extracellular matrix (ECM) substrates deposited on fluoropolymers show weak cell adhesion in this study. In this study, we took advantage of this property and developed a new spheroid fabrication method that simultaneously satisfies all of the above requirements for spheroid production by forming an ECM dot pattern on the fluoropolymer, which allows cells to adhere on 
it, retain it during cell growth, and detach from the fluoropolymer without employing damaging enzymatic treatments.

\section{Materials and Methods}

\subsection{Spheroid Culture Scaffold Fabrication}

A fluoropolymer surface was formed by coating a glass substrate with CYTOPТM (CTL-107MK; AGC Chemicals, Tokyo, Japan). CYTOPTM is a fluoropolymer product with properties similar to polytetrafluoroethylene (PTFE) $[67,68]$. This resin has fluoropolymer properties, such as water repellency, oil repellency, and chemical resistance, as well as high transparency, which are difficult to obtain with crystalline resins, such as PTFE. It can also be used for cell culture observation using an inverted microscope because it has no fluorescence properties. The material was immersed in a dip solution consisting of CYTOP $^{\mathrm{TM}}$ and a 16-fold dilution of a thinner solution (CT-Solv.100; AGC Chemicals) to coat the glass substrate (Table 1). The pull-out and curing conditions were as recommended by the manufacturer. The material was pulled out at a speed of approximately $1 \mathrm{~mm} / \mathrm{s}$ and cured in an oven at $100{ }^{\circ} \mathrm{C}$ for at least $90 \mathrm{~min}$.

\subsection{Preparation of a Stamp for Patterning Formation}

The dot patterns of the ECM were fabricated using a microstamp made out of polydimethylsiloxane (PDMS; SYLGARD ${ }^{\mathrm{TM}} 184$; Dow Toray, Tokyo, Japan). PDMS has high biological safety [69-73] and is also used in engineering to transfer fine patterns [74]. To fabricate the microstamp, PDMS mixed with a hardener was poured into a mold made of PTFE, after which the mold was defoamed. After defoaming, the stamps were heat-cured at $90{ }^{\circ} \mathrm{C}$ for $90 \mathrm{~min}$. The dimensions of the stamps were $100 \mu \mathrm{m}$ in spheroid diameter (the size at which spheroid necrosis does not occur [75-77]), $800 \mu \mathrm{m}$ in dot size diameter, and a $7 \times 7$ matrix arrangement with a pitch of $1500 \mu \mathrm{m}$. The dot diameter was defined as the area where the volume of a cell sheet cultured in a monolayer on the dot pattern is equivalent to a spheroid $100 \mu \mathrm{m}$ in diameter, assuming that one cell is a sphere with a diameter of $10 \mu \mathrm{m}$. The dimensions of the molds and microstamps were measured using an OLS-5000 (Olympus, Tokyo, Japan).

\subsection{Patterning of the Extracellular Matrix}

ECM substrates, including Matrigel Growth Factor Reduced (354230; Corning, NY, USA), iMatrix-511 silk (892021; Nippi, Tokyo, Japan), fibronectin (33016015; Thermo Fisher Scientific, Waltham, MA, USA), vitronectin (A31804; Thermo Fisher Scientific, Waltham, MA, USA), and collagen IV (ASC-4-104-01; Nippi), were diluted in RPMI 1640 (30264-56; Nacalai Tesque, Kyoto, Japan) 2-, 4-, 8-, and 16-fold. PDMS stamps dipped in ECM diluent were stamped onto the substrates, after which the ECM was transferred to the fluoropolymer surface with the formed pattern and incubated at $37^{\circ} \mathrm{C}$ and $5 \% \mathrm{CO}_{2}$ for $1 \mathrm{~h}$. After incubation, the substrates were washed with RPMI 1640.

\subsection{Cell Culture}

HepG2 (TKG02058) and MCF7 (TKG0479) cells were provided by the Cell Resource Center for Biomedical Research, Institute of Development, Aging and Cancer, Tohoku University, Japan. The cells were cultured in Dulbecco's modified Eagle's medium (DMEM; 5919, Nissi, Tokyo, Japan.) supplemented with 10\% fetal bovine serum (FBS; BioWest, Nuaillé, France), 2 mM L-Alanyl-L-glutamine solution (01102-82, Nacalai Tesque) and Penicillin-Streptomycin Mixed Solution (26252-94, Nacalai Tesque) (10\%FBS/DMEM.) for $37^{\circ} \mathrm{C}$ at $5 \% \mathrm{CO}_{2}$ and $95 \%$ air. The cells were passaged every 3 days at a ratio of $1: 3$, using TE dissociation buffer containing $0.25 \%$ trypsin (35547-64; Nacalai Tesque) and 0.04\% EDTA (15105-35; Nacalai Tesque). 


\subsection{Spheroid Preparation}

The ECM was transferred to the fluoropolymer-coated substrate, using a microstamp (Figure 1a). Cells were then evenly seeded at $1.0 \times 10^{4}$ cells $/ \mathrm{cm}^{2}$ on the substrate and allowed to evenly adhere (Figure 1b). After 7 days, the cells proliferated and formed colonies only on the ECM-coated area (Figure 1c). These cell colonies were detached by gently pipetting, followed by culturing in suspension for 7 days until spheroid formation (Figure 1d). All cultures were performed on fluoropolymer-coated glass substrate in a 5-well petri dish (NM-CD-5F, Naka Medical, Tachikawa, Japan).

(a)

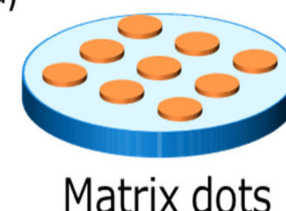

(b)

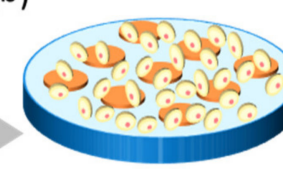

Day 1 (c)

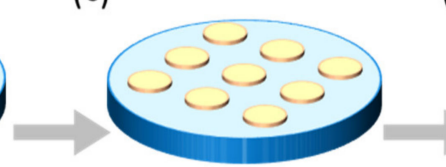

Day 7 (d)

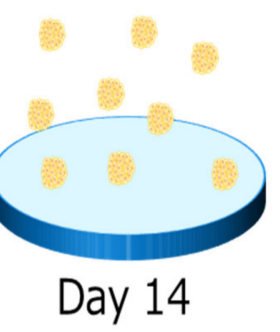

Figure 1. Schematic diagram of the spheroid production process. (a) Matrix transferred by stamping. (b) Cell adhesion occurring one day after seeding. (c) Cell colony formation 7 days after seeding. (d) After detaching the cells, spheroids formed in suspension by day 14 .

Spheroids were produced by the hanging drop method. The average number of cells in the dot pattern colonies was estimated, and they were seeded to form a spheroid. Briefly, the cells were grown until confluent. Single cells were then dissociated using TE buffer. The number of cells was counted, and spheroids were prepared by seeding $8 \times 10^{3}$ cells/drop using the hanging drop method.

\subsection{Evaluation of Cell Patterning}

All ECM and cell patterning were observed using a phase-contrast microscope and then photographed and dimensioned using FLOYD-4K (Wraymer, Osaka, Japan). The diameter of the ECM was measured, but as cell colonies and spheroids do not form a perfect circle, the equivalent diameter of a circle was calculated from the area. Photographs were acquired of the coated ECM dimensions, colony size after cell seeding (day 1), cell sheet dimensions left as a pattern on the ECM (day 7), and spheroid size (days 10-14).

\subsection{Measurement of Spheroid Viability Using Trypan Blue Staining}

The cells of the 2D culture and spheroids were dissociated using TE buffer, and a single cell suspension was obtained. The cells in the suspension were then stained with trypan blue (35535-02, Nacalai Tesque) to determine the number of viable cells. Student $t$-test was performed to compare survival rates between the $2 \mathrm{D}$ culture and spheroids.

\section{Results}

\subsection{Water Repellency of Fluoropolymers}

The contact angle measurements were conducted to measure the surface free energy, which is mainly responsible for fluoropolymer inertness in cells. The contact angles for a 2-, 4-, 8-, and 16 -fold dilution were $113.36^{\circ}, 115.00^{\circ}, 114.31^{\circ}$, and $112.58^{\circ}$, respectively, showing good water repellency, even at a 16 -fold dilution. In consideration of economic efficiency, we used a 16-fold dilution of CYTOP'M for coating (Table 1). 
Table 1. Contact angle measurement results for the different CYTOP ${ }^{\mathrm{TM}}$ dilutions.

\begin{tabular}{|c|c|c|c|c|}
\hline Dilution Rate & $2 x$ & $4 x$ & $8 x$ & $16 x$ \\
\hline $\begin{array}{c}\text { Contact angle } \\
\text { (degree) }\end{array}$ & 113.36 & 115.00 & 114.31 & 112.58 \\
\hline $\begin{array}{l}\text { Left angle } \\
\text { (degree) }\end{array}$ & 114.09 & 115.18 & 114.53 & 112.51 \\
\hline $\begin{array}{l}\text { Right angle } \\
\text { (degree) }\end{array}$ & 112.62 & 114.81 & 114.09 & 112.65 \\
\hline $\begin{array}{l}\text { Height from top to base } \\
\text { (mm) }\end{array}$ & 3.97 & 3.98 & 4.00 & 4.03 \\
\hline $\begin{array}{c}\text { Base line length } \\
(\mathrm{mm})\end{array}$ & 5.48 & 5.30 & 5.48 & 5.61 \\
\hline $\begin{array}{l}\text { Base area } \\
\left(\mathrm{mm}^{2}\right)\end{array}$ & 23.60 & 22.03 & 23.60 & 24.67 \\
\hline $\begin{array}{l}\text { Drop volume } \\
\qquad(\mu \mathrm{L})\end{array}$ & 60.06 & 55.21 & 60.74 & 63.64 \\
\hline $\begin{array}{l}\text { Wetting energy } \\
(\mathrm{mN} / \mathrm{m})\end{array}$ & -28.86 & -30.76 & -29.97 & -27.95 \\
\hline $\begin{array}{l}\text { Spreading coefficient } \\
\qquad(\mathrm{mN} / \mathrm{m})\end{array}$ & 101.66 & 103.56 & 102.77 & 100.75 \\
\hline $\begin{array}{l}\text { Work of adhesion } \\
(\mathrm{mN} / \mathrm{m})\end{array}$ & 43.94 & 42.04 & 42.83 & 44.85 \\
\hline Photo & & & & \\
\hline
\end{tabular}

\subsection{Dimensional Reproducibility of the Microstamps}

After fabricating the microstamp with PDMS, we measured the dimensions of the top surface of the dots and found an average of $825.24 \mu \mathrm{m}, \sigma$ of $4.96 \mu \mathrm{m}$, and the shape diameter that was close to the target of $800 \mu \mathrm{m}$ with small variations (Figure 2).
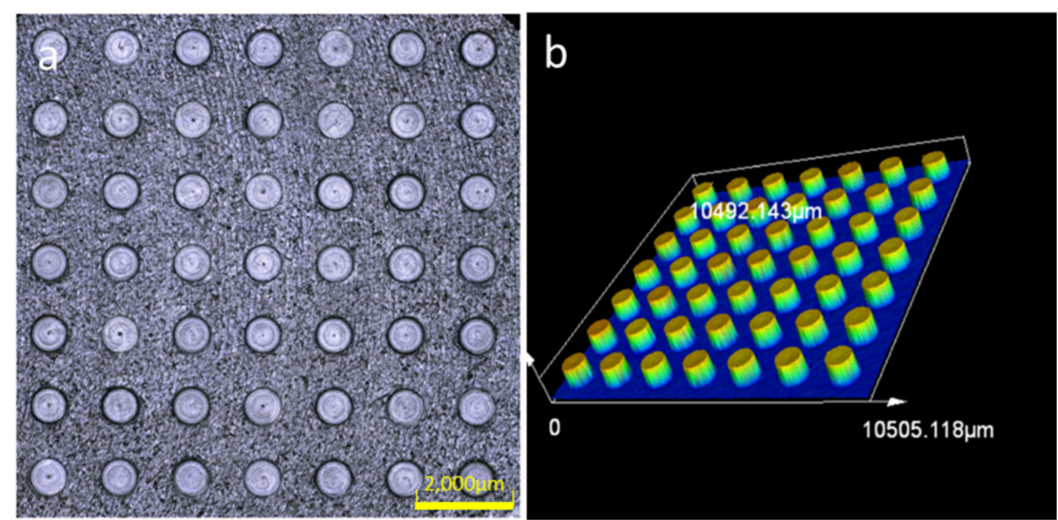

Figure 2. Observation of the top surface of a micro stamp using a laser microscope. (a) Optical imaging of a microstamp; (b) 3D image by a laser.

\subsection{Culturing HepG2 Cells on the Matrigel Pattern}

Matrigel was transferred to the fluoropolymer-coated substrate using a microstamp with an average pattern diameter of $898.74 \pm 140.69 \mu \mathrm{m}$ (Figure 3a,e: matrix transferred using a microstamp). HepG2 cells were seeded on this substrate and found to be uniformly adhered to the entire surface by day 1 (Figure $3 b$ ). The medium was gently changed every 2-3 days to avoid detaching the cells. By day 7, the cells had formed circular colonies based on the stamp pattern with an average colony diameter of $930.11 \pm 178.47 \mu \mathrm{m}$ 
(Figure 3c,e). After detaching the colonies from the substrate by weak pipetting and culturing in suspension, they spontaneously formed spheroids by day 8 and completely spheroidized by day 14. The average spheroid size was $466.23 \pm 75.25 \mu \mathrm{m}$ (Figure 3d,e, and Supplementary Figure S1).
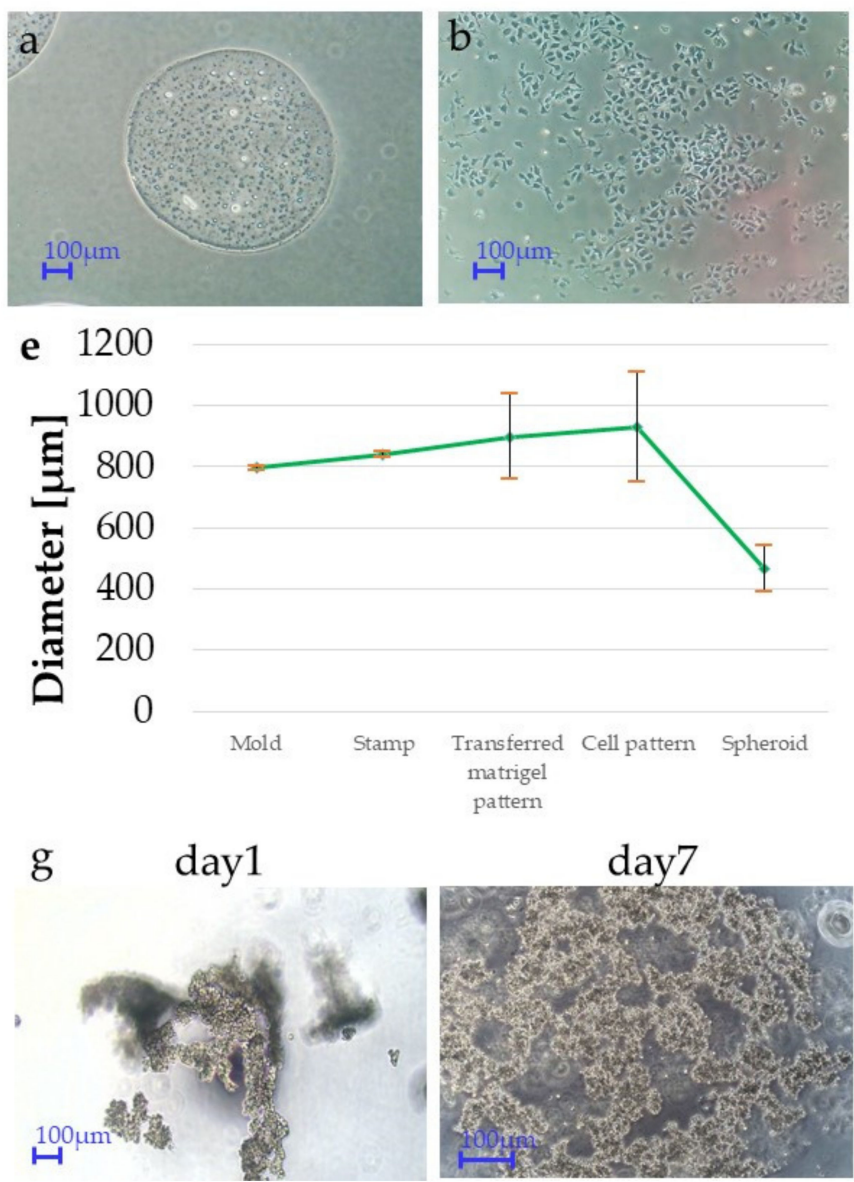
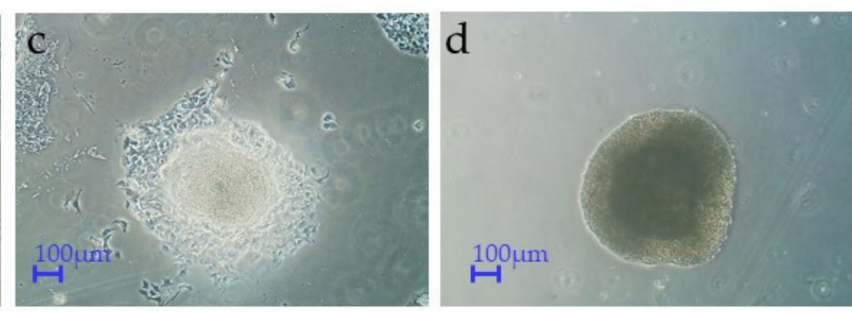

f
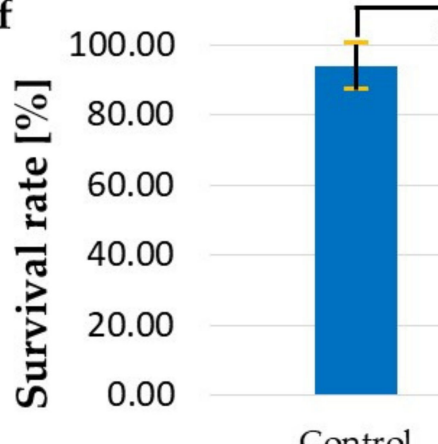

* $\mathrm{P}=0.05$

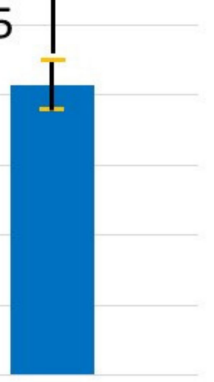

Spheroid

Figure 3. Bright-field image of HepG2 cultured on Matrigel dots and chart of size on every stage. (a) Stamped ECM (Matrigel) on the fluoropolymer surface. (b) HepG2 cells 1 day after seeding. (c) HepG2 cells grown to a colony of the same size as that of the Matrigel pattern on day 7. (d) Day 14 spheroids derived from detached HepG2 cells grown in suspension after culturing in 2D for 7 days on Matrigel. (e) The average diameter of the dot patterns during each step as shown in (a-d). Error bars indicate the standard deviation. (f) Viability confirmation by trypan blue staining. Student $t$-test was performed to compare survival rates between the $2 \mathrm{D}$ and spheroid $(p=0.05)$. $p$ value $<0.05$ was considered statistically significant. Data are expressed as means \pm standard deviations. The asterisks $\left(^{*}\right)$ indicate a statistically significant difference. (g) HepG2 on days 1 and 7 following the hanging-drop method.

Trypan blue staining was performed to determine the viability of the prepared spheroids. The survival rate of the HepG2 cells as estimated by trypan blue staining was $93.95 \pm 6.56 \%$ in $2 \mathrm{D}$ culture and $82.84 \pm 6.99 \%$ in the spheroids derived by our method (Figure 3f). Next, spheroid formation was monitored for 7 days using the hanging-drop method; however, no HepG2-derived spheroids were observed (Figure 3g).

\subsection{Culturing HepG2 Cells on Other Extracellular Matrix Patterns}

We used other ECM substrates and the MCF7 cell line to determine whether spheroids formed using other combinations besides Matrigel and HepG2 cells. Using the other ECM substrates, including iMatrix (fragmented laminin), vitronectin, fibronectin, and collagen IV dot patterns also formed. The seeded HepG2 cells successfully adhered to these ECM substrates, after which colonies formed by day 7 and spheroids by day 14 (Figure 4(a1a5)). Similar to HeG2 cells, seeded MCF7 cells formed colonies 7 days after seeding and 
spheroids by day 14 after the suspension culture (Figure 4(b1-b5)). When the cells were continuously cultured in 2D without detaching by day 7 , the cells continued to proliferate and became over confluent on the ECM dots by day 10. Subsequently, the cells no longer proliferated in the monolayer, due to the influence of non-adhesive areas outside the colony pattern but instead proliferated toward the upper part of the colony and partially formed a spheroid. This phenomenon was also observed with HepG2 cells, indicating that it is difficult to control spheroid diameter within the area of the pattern when using cell lines with high proliferation ability.
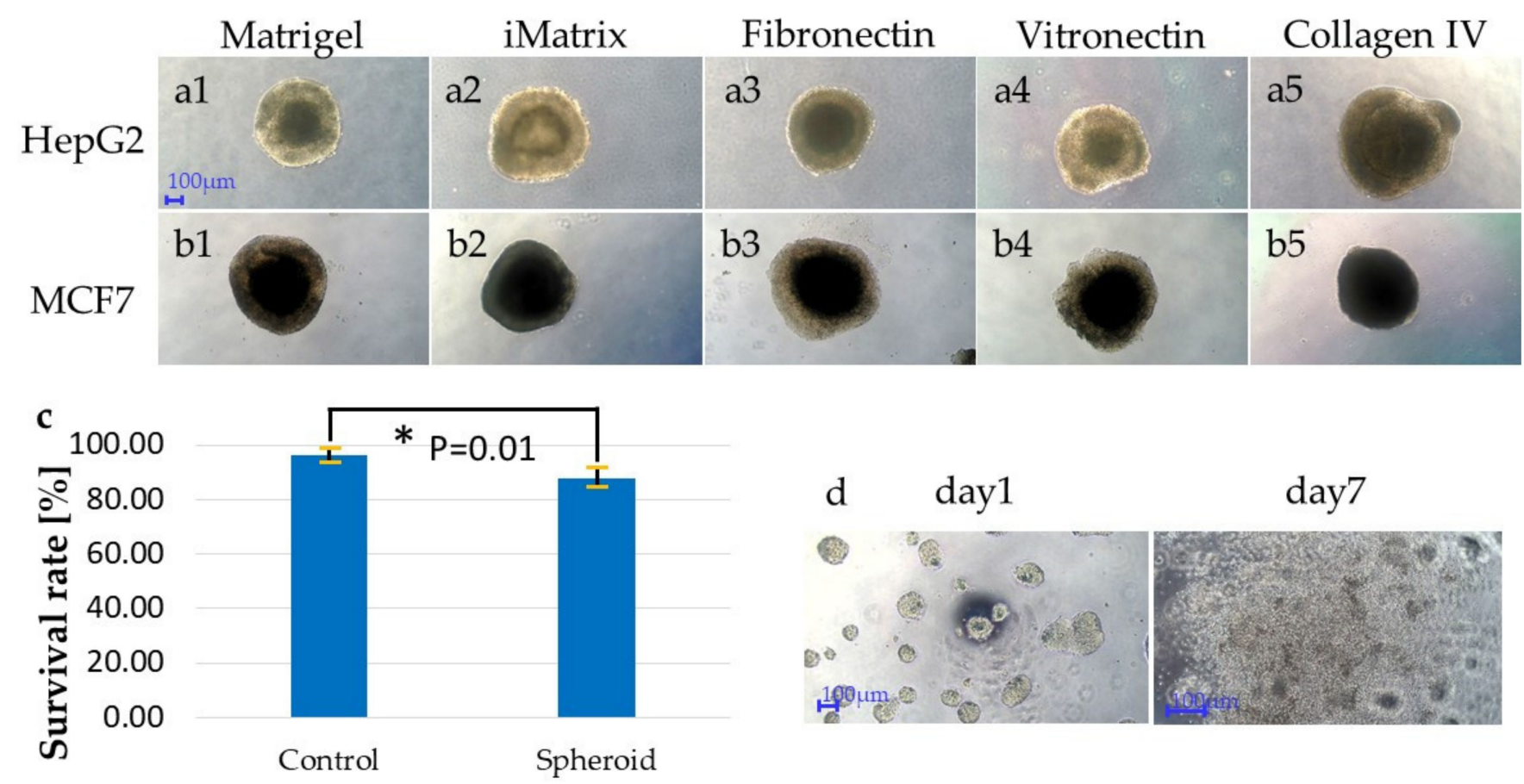

Figure 4. Spheroids derived from HepG2 or MCF7 cells after culturing in 2D for 7 days on different ECM substrates. HepG2 cells seeded on Matrigel (a1), Matrix (a2), fibronectin (a3), vitronectin (a4), and collagen IV (a5). MCF7 cells seeded on Matrigel (b1), Matrix (b2), fibronectin (b3), vitronectin (b4), and collagen IV (b5). (c) Viability confirmation by trypan blue staining. Student $t$-test was performed to compare the survival rates between the 2D and spheroid ( $p=0.01)$. $p$ value $<0.05$ was considered statistically significant. Data are expressed as means \pm standard deviations. The asterisks $\left(^{*}\right)$ indicate a statistically significant difference. (d) MCF7 on days 1 and 7 following the hanging-drop method.

In MCF7 and matrigel, trypan blue staining was performed to determine the viability of spheroids from colonies; the survival rate of MCF7 in trypan blue was $96.09 \pm 2.82 \%$ in $2 \mathrm{D}$ culture and $87.89 \pm 3.62 \%$ in the spheroids derived by our method (Figure 4c). Next, spheroid formation was monitored for 7 days, using the hanging drop method. MCF7derived spheroids with a diameter of approximately 100-200 um were observed on day 1; however, no larger-sized spheroids were observed (Figure 4d).

\section{Discussion}

In the present study, all tested ECM substrates were successfully scaffolded on a fluoropolymer, and both HepG2 and MCF7 cell lines formed spheroids after culturing, without negatively affecting the cell population. The key to achieving this was the combination of the fluoropolymer and ECM dot pattern. Fluoropolymers are generally known to be difficult regarding adhesion; thus, many studies have attempted to improve adhesion by surface modification [78]. However, we showed that cells can adhere to the substrate via an ECM that can be detached easily by pipetting.

The survival rate of the spheroids derived using our method was significantly lower than that of the cells in the 2D culture. The reason for this was speculated to be the 
lack of space for cell growth inside the spheroid and the lack of nutrient circulation in the culture medium. For cancer spheroids, however, a slight decrease in survival are permitted; there are, accordingly, no disadvantages of our method. In addition, the hanging drop method could not produce large-sized spheroids in 7 days, but our method was effective in producing such large spheroids. It was also found to be more efficient because increasing the number of seeded cells could reduce the number of days required for spheroid formation (data not shown). These results suggest that our method can also be applied to spheroids derived from cancer cells.

We assume that our method would be useful in cases where cells of interest are induced from pluripotent stem cells, such as iPSCs, to produce spheroids. This method involves the process of culturing in 2D for a period of time to proliferate and induce, and the process of creating spheroids to confirm the functionality of the cells of interest. Therefore, the first half of the experiment (about 7 days) was assumed to be the cell proliferation and differentiation stage and the second half was assumed to involve the production of spheroids. We assume that the greatest benefit of producing spheroids in this way is the elimination of chemical and physical stimuli. The cell line was passaged using an enzyme but was not used to produce spheroids. Since the cell line used here is passaged every $2-4$ days, we minimized the effect of enzyme treatment on cells by assigning 7 days for colony formation. Thus, when increasing the seeding amount and attempting spheroidization in a short period of time, it is necessary to consider the effect of enzyme treatment.

Fluoropolymers have a high biocompatibility and inertness due to their non-polarity and strong C-F bonds. They are, thus, a safe and non-toxic material for use in the living body. Their high inertness entails advantages, such as a low adhesion in vivo, while their hampered in vivo settling is a problem for biomaterials. Their symmetrical molecular structure makes them chemically resistant and stable against most chemicals, including acids, alkalis, and organic chemicals. However, they can react slightly with molten alkali metals and their solutions as well as fluorine and chlorine trifluoride at high temperatures. Therefore, the ECM used in this study was not expected to form strong chemical bonds. In addition, the non-polar molecular structure does not allow for electrical bonds, such as hydrogen bonds. Nevertheless, the cells were able to adhere to the ECM that was transferred onto the fluoropolymer (Figure 3a,c). Hydrophobic interactions [79] and the surface charge of the fluoropolymer [78] were reported as possible mechanisms underlying this adhesion. However, we believe that van der Waals forces are instead responsible because of the weak adhesive force that allowed cells to peel off over time regardless of the ECM type. During formation of the ECM dots, the ECM floating in the culture medium settled down due to gravity and gathered on the substrate surface after the gel-like protein molecules (matrix components) were stamped. As a result, the distance between the protein molecules and the fluoropolymer surface approached zero, and subsequently, the protein molecules adhered to the fluoropolymer surface via van der Waals forces. Van der Waals forces are extremely weak compared with chemical bonds and hydrogen bonds. Therefore, when the cells proliferated and the tension between them increased, the cells began to detach from the edges of the cell colonies and were easily peeled off from the ECM-coated fluoropolymer surface upon pipetting with a weak liquid flow.

If the ECM indeed adheres via van der Waals forces, the question is why the fluoropolymer does not allow adhesion of other substances and is considered an inert material. This may be because the objects to which the fluoropolymer adheres are usually considered solids. The surfaces of solids possess microscopic irregularities, which are shown in Figure 5a. There are many gaps between the solid and the surface of the fluoropolymer. Because van der Waals forces are only generated when the distance is very short, the area ratio of the contact point to the entire interface is extremely small with solids; if the contact area/external force ratio is large, the adhesive force increases. Therefore, in many cases, it is impossible to obtain an attractive force sufficient to hold the entire solid against external forces. In contrast, when the object to be adhered is a liquid (Figure 5b), there is no gap, 
and the molecules are in close contact with each other. However, the molecules in the liquid move over long distances, and the van der Waals forces are not strong enough to overcome their kinetic energy and maintain the molecules at the interface. If the attractive forces are strong, the contact angle should be small, but this is not the case. Furthermore, because of the flow phenomenon, i.e., the shape of the entire liquid can freely change, it is not possible for the liquid to stay in place. In contrast, water $\left(\mathrm{H}_{2} \mathrm{O}\right)$ can remain on a glass surface because of the presence of a larger number of hydrogen bonds than in silicone oil. Moreover, when highly viscous silicone oil with extremely low polarity is dropped onto a fluoropolymer, the surface becomes wet easily, and the oil remains on the surface, even if it is physically wiped off. The ECM used in the present study [79-84] is a gel with properties between those of a solid and liquid (Figure 5c); it can be deformed to the extent that no gaps are created between it and the fluoropolymer surface. We thus concluded that the protein molecules adhered to the fluoropolymer surface via van der Waals forces.
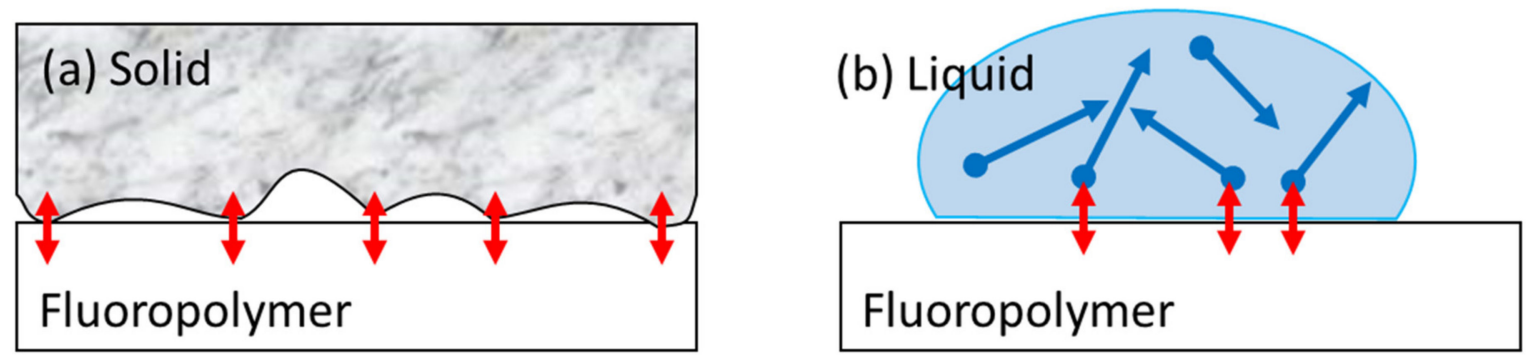

(c) Gel

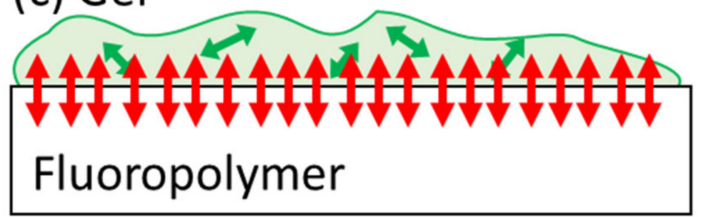

$\uparrow$ Van der Waals force

Molecular movement

Figure 5. Application of force to the fluoropolymer depending on the state of the material placed on its surface. (a) Only point contact is possible due to the fine surface irregularities of solids, and thus, the area contributing to van der Waals forces is small. (b) Molecular motion in a spherically curled liquid as the surface tension exceeds the attractive van der Waals forces. (c) A gel with low surface tension and low fluidity is more densely packed, and the van der Waals forces act over a large area.

In this study, the dimensions of the spheroids were too large compared to the dimensions of the 2D matrix dots (Figure 3e). The reason is considered to be that cell lines were used here. Seven days after seeding, it was observed that the number of cell in the colony exceeded that in the 2D confluent state and proliferate in the 3D layer. If the colonies were detached by pipetting before that, the spheroid size could be controlled. In the future, the proposed method will be employed to spheroids using stem cells, and in that case, such a problem could be automatically avoided. At that time, we expect that it will also be possible to induce all cells in a planar manner at the 2D culture stage, and then suspend them while maintaining the generated cell polarity to create 3D cells using our method. In a conventional method, when a differentiation factor is added to stem cells after spheroidization, the differentiation factor may act only on the surface of the spheroid, and the induction of target cells may be insufficient in the central part. In a conventional method, when a differentiation factor is added to stem cells after spheroidization, the differentiation factors may act only on the surface of the spheroid, which can lead to insufficient induction of the target cells in the central part. In another conventional method, when a differentiation factor is added to stem cells before spheroidization, the cell substrate will be degraded during detachment via enzymatic treatment, and the cell polarity formed by 2D culture will be destroyed. Furthermore, enzymatic treatment destroys cell-cell adhesion factors, which may adversely affect the efficiency of spheroid production. Our proposed method 
can solve those problems and is intended to be used for drug discovery and regenerative medicine research in the future $[75,85]$. We believe that this method will enable to obtain spheroids of stable quality in a simple and low-cost manner, which will contribute to the development of medicine.

\section{Conclusions}

We have developed a technique for generating spheroids that consists of $2 \mathrm{D}$ cell culture on ECM dot patterns deposited on a fluoropolymer scaffold, followed by cell colony detachment from the substrate and suspension culture. The ECM substrate was weakly bound onto the fluoropolymer surface, and thus, the adherent cell colonies were easily detached by gentle pipetting; we theorized that van der Waals forces were responsible for this weak adhesion. Spheroid formation was successful with all tested combinations of five ECM substrates (Matrigel, iMatrix, fibronectin, vitronectin, and collagen IV) and two cell lines (HepG2 and MCF7). When forming spheroids during the differentiation process of pluripotent stem cells, in contrast to conventional methods, our technique enabled spheroidization without chemical (via enzymatic treatment) or physical stimulation, and thus, a more stable spheroid production could be obtained. For spheroids such as cancer cells and cells established from tissues, however, the chemical and physical stimuli are the same as those for the conventional method. Moreover, the technique is relatively uncomplicated and is expected to be low in cost. In future studies, we will test the effect of the ECM pattern size on the spheroid size and assess differentiation induction using this scaffold to establish size controllability and a method for iPSC spheroid/organoid production. We anticipate that such spheroid/organoids can be used for drug discovery and regenerative medicine.

Supplementary Materials: The following are available online at https:/ /www.mdpi.com/article/10 .3390/app112110495/s1, Figure S1: Detailed measurement at each stage.

Author Contributions: Conceptualization, H.T. (Hidetaka Togo), H.T. (Hiroki Takeuchi) and M.K.; methodology, H.T. (Hidetaka Togo), H.T. (Hiroki Takeuchi) and M.K.; validation, H.T. (Hidetaka Togo), K.Y.-T. and Y.H.; formal analysis, H.T. (Hidetaka Togo); investigation, H.T. (Hidetaka Togo), K.Y.-T. and Y.H.; resources, H.T. (Hiroki Takeuchi) and M.K.; data curation, H.T. (Hidetaka Togo) and K.Y.-T.; writing—original draft preparation, H.T. (Hidetaka Togo); writing—review and editing, H.T. (Hiroki Takeuchi) and M.K.; visualization, H.T. (Hidetaka Togo); supervision, H.N.; project administration, M.K.; funding acquisition, H.T. (Hiroki Takeuchi) and M.K. All authors have read and agreed to the published version of the manuscript.

Funding: This research was supported by JST A-STE, grant number JPMJTR20UC (to M.K.) and JSPS KAKENHI grant numbers JP18K16768, 20K18188 (to H.T. (Hiroki Takeuchi)).

Institutional Review Board Statement: Not applicable.

Informed Consent Statement: Not applicable.

Conflicts of Interest: The authors declare no conflict of interest.

\section{References}

1. Bhadriraju, K.; Chen, C.S. Engineering cellular microenvironments to improve cell-based drug testing. Drug Discov. Today 2002, 7, 612-620. [CrossRef]

2. Breslin, S.; O'Driscoll, L. Three-dimensional cell culture: The missing link in drug discovery. Drug Discov. Today 2013, 18, 240-249. [CrossRef]

3. Nath, S.; Devi, G.R. Three-dimensional culture systems in cancer research: Focus on tumor spheroid model. Pharmacol. Ther. 2016, 163, 94-108. [CrossRef]

4. Riedl, A.; Schlederer, M.; Pudelko, K.; Stadler, M.; Walter, S.; Unterleuthner, D.; Unger, C.; Kramer, N.; Hengstschläger, M.; Kenner, L.; et al. Comparison of cancer cells in 2D vs 3D culture reveals differences in AKT-mTOR-S6K signaling and drug responses. J. Cell Sci. 2017, 130, 203-218. [CrossRef] [PubMed]

5. Birgersdotter, A.; Sandberg, R.; Ernberg, I. Gene expression perturbation in vitro-a growing case for three-dimensional (3D) culture systems. Semin. Cancer Biol. 2005, 15, 405-412. [CrossRef] 
6. Goetz, M.P.; Rae, J.M.; Suman, V.J.; Safgren, S.L.; Ames, M.M.; Visscher, D.W.; Reynolds, C.; Couch, F.J.; Lingle, W.L.; Flockhart, D.A.; et al. Pharmacogenetics of tamoxifen biotransformation is associated with clinical outcomes of efficacy and hot flashes. $J$. Clin. Oncol. 2005, 23, 9312-9318. [CrossRef] [PubMed]

7. Achilli, T.M.; Meyer, J.; Morgan, J.R. Advances in the formation, use and understanding of multi-cellular spheroids. Expert Opin. Biol. 2012, 12, 1347-1360. [CrossRef]

8. Egawa, N.; Kitaoka, S.; Tsukita, K.; Naitoh, M.; Takahashi, K.; Yamamoto, T.; Adachi, F.; Kondo, T.; Okita, K.; Asaka, I.; et al. Drug screening for ALS using patient-specific induced pluripotent stem cells. Sci. Transl. Med. 2012, 4, 145ra104. [CrossRef]

9. Kondo, T.; Asai, M.; Tsukita, K.; Kutoku, Y.; Ohsawa, Y.; Sunada, Y.; Imamura, K.; Egawa, N.; Yahata, N.; Okita, K.; et al. Modeling Alzheimer's disease with iPSCs reveals stress phenotypes associated with intracellular A $\beta$ and differential drug responsiveness. Cell Stem Cell 2013, 12, 487-496. [CrossRef]

10. Hino, K.; Ikeya, M.; Horigome, K.; Matsumoto, Y.; Ebise, H.; Nishio, M.; Sekiguchi, K.; Shibata, M.; Nagata, S.; Matsuda, S.; et al. Neofunction of ACVR1 in fibrodysplasia ossificans progressiva. Proc. Natl. Acad. Sci. USA 2015, 112, 15438-15443. [CrossRef] [PubMed]

11. Ishii, T.; Ishikawa, M.; Fujimori, K.; Maeda, T.; Kushima, I.; Arioka, Y.; Mori, D.; Nakatake, Y.; Yamagata, B.; Nio, S.; et al. In Vitro Modeling of the Bipolar Disorder and Schizophrenia Using Patient-Derived Induced Pluripotent Stem Cells with Copy Number Variations of PCDH15 and RELN. eNeuro 2019, 6. [CrossRef]

12. Shiba, M.; Higo, S.; Kondo, T.; Li, J.; Liu, L.; Ikeda, Y.; Kohama, Y.; Kameda, S.; Tabata, T.; Inoue, H.; et al. Phenotypic recapitulation and correction of desmoglein-2-deficient cardiomyopathy using human-induced pluripotent stem cell-derived cardiomyocytes. Hum. Mol. Genet. 2021, 30, 1384-1397. [CrossRef] [PubMed]

13. Kondo, T.; Imamura, K.; Funayama, M.; Tsukita, K.; Miyake, M.; Ohta, A.; Woltjen, K.; Nakagawa, M.; Asada, T.; Arai, T.; et al. iPSC-Based Compound Screening and In Vitro Trials Identify a Synergistic Anti-amyloid $\beta$ Combination for Alzheimer's Disease. Cell Rep. 2017, 21, 2304-2312. [CrossRef] [PubMed]

14. Hino, K.; Zhao, C.; Horigome, K.; Nishio, M.; Okanishi, Y.; Nagata, S.; Komura, S.; Yamada, Y.; Toguchida, J.; Ohta, A.; et al. An mTOR Signaling Modulator Suppressed Heterotopic Ossification of Fibrodysplasia Ossificans Progressiva. Stem Cell Rep. 2018, 11, 1106-1119. [CrossRef] [PubMed]

15. Yamaguchi, A.; Ishikawa, K.I.; Inoshita, T.; Shiba-Fukushima, K.; Saiki, S.; Hatano, T.; Mori, A.; Oji, Y.; Okuzumi, A.; Li, Y.; et al. Identifying Therapeutic Agents for Amelioration of Mitochondrial Clearance Disorder in Neurons of Familial Parkinson Disease. Stem Cell Rep. 2020, 14, 1060-1075. [CrossRef] [PubMed]

16. Shimizu, T.; Mae, S.I.; Araoka, T.; Okita, K.; Hotta, A.; Yamagata, K.; Osafune, K. A novel ADPKD model using kidney organoids derived from disease-specific human iPSCs. Biochem. Biophys. Res. Commun. 2020, 529, 1186-1194. [CrossRef]

17. Shiihara, M.; Ishikawa, T.; Saiki, Y.; Omori, Y.; Hirose, K.; Fukushige, S.; Ikari, N.; Higuchi, R.; Yamamoto, M.; Morikawa, T.; et al. Development of a system combining comprehensive genotyping and organoid cultures for identifying and testing genotype-oriented personalised medicine for pancreatobiliary cancers. Eur. J. Cancer 2021, 148, 239-250. [CrossRef]

18. Crespo, M.; Vilar, E.; Tsai, S.Y.; Chang, K.; Amin, S.; Srinivasan, T.; Zhang, T.; Pipalia, N.H.; Chen, H.J.; Witherspoon, M.; et al. Colonic organoids derived from human induced pluripotent stem cells for modeling colorectal cancer and drug testing. Nat. Med. 2017, 23, 878-884. [CrossRef]

19. Cui, X.; Hartanto, Y.; Zhang, H. Advances in multicellular spheroids formation. J. R. Soc. Interface 2017, 14, 20160877. [CrossRef]

20. Ivascu, A.; Kubbies, M. Rapid generation of single-tumor spheroids for high-throughput cell function and toxicity analysis. $J$. Biomol. Screen. 2006, 11, 922-932. [CrossRef]

21. Masuda, T.; Takei, N.; Nakano, T.; Anada, T.; Suzuki, O.; Arai, F. A microfabricated platform to form three-dimensional toroidal multicellular aggregate. Biomed. Microdevices 2012, 14, 1085-1093. [CrossRef] [PubMed]

22. Thomsen, A.R.; Aldrian, C.; Bronsert, P.; Thomann, Y.; Nanko, N.; Melin, N.; Rücker, G.; Follo, M.; Grosu, A.L.; Niedermann, G.; et al. A deep conical agarose microwell array for adhesion independent three-dimensional cell culture and dynamic volume measurement. Lab Chip 2017, 18, 179-189. [CrossRef] [PubMed]

23. Uchida, H.; Machida, M.; Miura, T.; Kawasaki, T.; Okazaki, T.; Sasaki, K.; Sakamoto, S.; Ohuchi, N.; Kasahara, M.; Umezawa, A.; et al. A xenogeneic-free system generating functional human gut organoids from pluripotent stem cells. JCI Insight 2017, 2, e86492. [CrossRef] [PubMed]

24. Chan, H.F.; Zhang, Y.; Ho, Y.P.; Chiu, Y.L.; Jung, Y.; Leong, K.W. Rapid formation of multicellular spheroids in double-emulsion droplets with controllable microenvironment. Sci. Rep. 2013, 3, 3462. [CrossRef]

25. Jang, M.; Koh, I.; Lee, S.J.; Cheong, J.H.; Kim, P. Droplet-based microtumor model to assess cell-ECM interactions and drug resistance of gastric cancer cells. Sci. Rep. 2017, 7, 41541. [CrossRef]

26. Yoshii, Y.; Waki, A.; Yoshida, K.; Kakezuka, A.; Kobayashi, M.; Namiki, H.; Kuroda, Y.; Kiyono, Y.; Yoshii, H.; Furukawa, T.; et al. The use of nanoimprinted scaffolds as 3D culture models to facilitate spontaneous tumor cell migration and well-regulated spheroid formation. Biomaterials 2011, 32, 6052-6058. [CrossRef]

27. Yamazaki, H.; Gotou, S.; Ito, K.; Kohashi, S.; Goto, Y.; Yoshiura, Y.; Sakai, Y.; Yabu, H.; Shimomura, M.; Nakazawa, K. Micropatterned culture of HepG2 spheroids using microwell chip with honeycomb-patterned polymer film. J. Biosci. Bioeng. 2014, 118, 455-460. [CrossRef]

28. Snyman, C.; Elliott, E. An optimized protocol for handling and processing fragile acini cultured with the hanging drop technique. Anal. Biochem. 2011, 419, 348-350. [CrossRef] 
29. Qian, X.; Nguyen, H.N.; Song, M.M.; Hadiono, C.; Ogden, S.C.; Hammack, C.; Yao, B.; Hamersky, G.R.; Jacob, F.; Zhong, C.; et al. Brain-Region-Specific Organoids Using Mini-bioreactors for Modeling ZIKV Exposure. Cell 2016, 165, 1238-1254. [CrossRef]

30. Yabe, S.G.; Fukuda, S.; Nishida, J.; Takeda, F.; Nashiro, K.; Okochi, H. Induction of functional islet-like cells from human iPS cells by suspension culture. Regen 2019, 10, 69-76. [CrossRef]

31. Hsiao, A.Y.; Torisawa, Y.S.; Tung, Y.C.; Sud, S.; Taichman, R.S.; Pienta, K.J.; Takayama, S. Microfluidic system for formation of PC-3 prostate cancer co-culture spheroids. Biomaterials 2009, 30, 3020-3027. [CrossRef]

32. Baudoin, R.; Griscom, L.; Prot, J.M.; Legallais, C.; Leclerc, E. Behavior of HepG2/C3A cell cultures in a microfluidic bioreactor. Biochem. Eng. J. 2011, 53, 172-181. [CrossRef]

33. Borys, B.S.; Le, A.; Roberts, E.L.; Dang, T.; Rohani, L.; Hsu, C.Y.; Wyma, A.A.; Rancourt, D.E.; Gates, I.D.; Kallos, M.S. Using computational fluid dynamics (CFD) modeling to understand murine embryonic stem cell aggregate size and pluripotency distributions in stirred suspension bioreactors. J. Biotechnol. 2019, 304, 16-27. [CrossRef]

34. Souza, G.R.; Molina, J.R.; Raphael, R.M.; Ozawa, M.G.; Stark, D.J.; Levin, C.S.; Bronk, L.F.; Ananta, J.S.; Mandelin, J.; Georgescu, M.M.; et al. Three-dimensional tissue culture based on magnetic cell levitation. Nat. Nanotechnol. 2010, 5, 291-296. [CrossRef]

35. Sebastian, A.; Buckle, A.M.; Markx, G.H. Tissue engineering with electric fields: Immobilization of mammalian cells in multilayer aggregates using dielectrophoresis. Biotechnol. Bioeng. 2007, 98, 694-700. [CrossRef] [PubMed]

36. Chen, K.; Wu, M.; Guo, F.; Li, P.; Chan, C.Y.; Mao, Z.; Li, S.; Ren, L.; Zhang, R.; Huang, T.J. Rapid formation of size-controllable multicellular spheroids via 3D acoustic tweezers. Lab Chip 2016, 16, 2636-2643. [CrossRef]

37. Heid, S.; Boccaccini, A.R. Advancing bioinks for 3D bioprinting using reactive fillers: A review. Acta Biomater. 2020, 113, 1-22. [CrossRef] [PubMed]

38. Aguilar, I.N.; Olivos, D.J., 3rd; Brinker, A.; Alvarez, M.B.; Smith, L.J.; Chu, T.G.; Kacena, M.A.; Wagner, D.R. Scaffold-free bioprinting of mesenchymal stem cells using the Regenova printer: Spheroid characterization and osteogenic differentiation. Bioprinting 2019, 15, e00050. [CrossRef]

39. Daly, A.C.; Kelly, D.J. Biofabrication of spatially organised tissues by directing the growth of cellular spheroids within 3D printed polymeric microchambers. Biomaterials 2019, 197, 194-206. [CrossRef]

40. Leclerc, E.; Sakai, Y.; Fujii, T. Perfusion culture of fetal human hepatocytes in microfluidic environments. Biochem. Eng. J. 2004, 20, 143-148. [CrossRef]

41. Awaja, F.; Gilbert, M.; Kelly, G.; Fox, B.; Pigram, P.J. Adhesion of polymers. Prog. Polym. Sci. 2009, 34, 948-968. [CrossRef]

42. Roina, Y.; Auber, F.; Hocquet, D.; Herlem, G. ePTFE functionalization for medical applications. Mater. Today Chem. 2021, 20, 100412-100443. [CrossRef]

43. Bacakova, L.; Filova, E.; Parizek, M.; Ruml, T.; Svorcik, V. Modulation of cell adhesion, proliferation and differentiation on materials designed for body implants. Biotechnol. Adv. 2011, 29, 739-767. [CrossRef] [PubMed]

44. Wang, H.; Kwok, D.T.; Wang, W.; Wu, Z.; Tong, L.; Zhang, Y.; Chu, P.K. Osteoblast behavior on polytetrafluoroethylene modified by long pulse, high frequency oxygen plasma immersion ion implantation. Biomaterials 2010, 31, 413-419. [CrossRef] [PubMed]

45. Lih, E.; Oh, S.H.; Joung, Y.K.; Lee, J.H.; Han, D.K. Polymers for cell/tissue anti-adhesion. Prog. Polym. Sci. 2015, 44, 28-61. [CrossRef]

46. Feng, S.; Zhong, Z.; Wang, Y.; Xing, W.; Drioli, E. Progress and perspectives in PTFE membrane: Preparation, modification, and applications. J. Membr. Sci. 2018, 549, 332-349. [CrossRef]

47. Bax, D.V.; McKenzie, D.R.; Weiss, A.S.; Bilek, M.M. The linker-free covalent attachment of collagen to plasma immersion ion implantation treated polytetrafluoroethylene and subsequent cell-binding activity. Biomaterials 2010, 31, 2526-2534. [CrossRef]

48. Bilek, M.M.M.; Vandrovcová, M.; Shelemin, A.; Kuzminova, A.; Kylián, O.; Biederman, H.; Bačáková, L.; Weiss, A.S. Plasma treatment in air at atmospheric pressure that enables reagent-free covalent immobilization of biomolecules on polytetrafluoroethylene (PTFE). Appl. Surf. Sci. 2020, 518, 146128. [CrossRef]

49. Cho, Y.K.; Park, D.; Kim, H.; Lee, H.; Park, H.; Kim, H.J.; Jung, D. Bioactive surface modifications on inner walls of poly-tetrafluoro-ethylene tubes using dielectric barrier discharge. Appl. Surf. Sci. 2014, 296, 79-85. [CrossRef]

50. Hajian, H.; Wise, S.G.; Bax, D.V.; Kondyurin, A.; Waterhouse, A.; Dunn, L.L.; Kielty, C.M.; Yu, Y.; Weiss, A.S.; Bilek, M.M.; et al. Immobilisation of a fibrillin-1 fragment enhances the biocompatibility of PTFE. Colloids Surf. B Biointerfaces 2014, 116, 544-552. [CrossRef] [PubMed]

51. Pu, F.R.; Williams, R.L.; Markkula, T.K.; Hunt, J.A. Expression of leukocyte-endothelial cell adhesion molecules on monocyte adhesion to human endothelial cells on plasma treated PET and PTFE in vitro. Biomaterials 2002, 23, 4705-4718. [CrossRef]

52. Gumpenberger, T.; Heitz, J.; Bäuerle, D.; Kahr, H.; Graz, I.; Romanin, C.; Svorcik, V.; Leisch, F. Adhesion and proliferation of human endothelial cells on photochemically modified polytetrafluoroethylene. Biomaterials 2003, 24, 5139-5144. [CrossRef]

53. Mikulikova, R.; Moritz, S.; Gumpenberger, T.; Olbrich, M.; Romanin, C.; Bacakova, L.; Svorcik, V.; Heitz, J. Cell microarrays on photochemically modified polytetrafluoroethylene. Biomaterials 2005, 26, 5572-5580. [CrossRef]

54. Svorcík, V. Cell proliferation on UV-excimer lamp modified and grafted polytetrafluoroethylene. Nucl. Instrum. Methods Phys. Res. Sect. B Beam Interact. Mater. At. 2004, 217, 307-313. [CrossRef]

55. Ahad, I.U.; Butruk, B.; Ayele, M.; Budner, B.; Bartnik, A.; Fiedorowicz, H.; Ciach, T.; Brabazon, D. Extreme ultraviolet (EUV) surface modification of polytetrafluoroethylene (PTFE) for control of biocompatibility. Nucl. Instrum. Methods Phys. Res. Sect. B Beam Interact. Mater. At. 2015, 364, 98-107. [CrossRef] 
56. Pérez-Calixto, M.; Diaz-Rodriguez, P.; Concheiro, A.; Alvarez-Lorenzo, C.; Burillo, G. Amino-functionalized polymers by gamma radiation and their influence on macrophage polarization. React. Funct. Polym. 2020, 151, 104568. [CrossRef]

57. Rosado, D.; Meléndez-Ortiz, H.I.; Ortega, A.; Gallardo-Vega, C.; Burillo, G. Modification of poly(tetrafluoroethylene) with polyallylamine by gamma radiation. Radiat. Phys. Chem. 2020, 172, 108766. [CrossRef]

58. Colwell, J.M.; Wentrup-Byrne, E.; Bell, J.M.; Wielunski, L.S. A study of the chemical and physical effects of ion implantation of micro-porous and nonporous PTFE. Surf. Coat. Technol. 2003, 168, 216-222. [CrossRef]

59. Gao, A.; Hang, R.; Li, W.; Zhang, W.; Li, P.; Wang, G.; Bai, L.; Yu, X.F.; Wang, H.; Tong, L.; et al. Linker-free covalent immobilization of heparin, SDF-1alpha, and CD47 on PTFE surface for antithrombogenicity, endothelialization and anti-inflammation. Biomaterials 2017, 140, 201-211. [CrossRef]

60. Kondyurina, I.; Shardakov, I.; Nechitailo, G.; Terpugov, V.; Kondyurin, A. Cell growing on ion implanted polytetrafluorethylene. Appl. Surf. Sci. 2014, 314, 670-678. [CrossRef]

61. Sommani, P.; Tsuji, H.; Kojima, H.; Sato, H.; Gotoh, Y.; Ishikawa, J.; Takaoka, G.H. Irradiation effect of carbon negative-ion implantation on polytetrafluoroethylene for controlling cell-adhesion property. Nucl. Instrum. Methods Phys. Res. Sect. B Beam Interact. Mater. At. 2010, 268, 3231-3234. [CrossRef]

62. Hou, Y.; Deng, X.; Xie, C. Biomaterial surface modification for underwater adhesion. Smart Mater. Med. 2020, 1, 77-91. [CrossRef]

63. Song, H.; Yu, H.; Zhu, L.; Xue, L.; Wu, D.; Chen, H. Durable hydrophilic surface modification for PTFE hollow fiber membranes. React. Funct. Polym. 2017, 114, 110-117. [CrossRef]

64. Talon, I.; Schneider, A.; Ball, V.; Hemmerle, J. Functionalization of PTFE Materials Using a Combination of Polydopamine and Platelet-Rich Fibrin. J. Surg Res. 2020, 251, 254-261. [CrossRef] [PubMed]

65. Ku, S.H.; Ryu, J.; Hong, S.K.; Lee, H.; Park, C.B. General functionalization route for cell adhesion on non-wetting surfaces. Biomaterials 2010, 31, 2535-2541. [CrossRef] [PubMed]

66. Yu, C.; Yang, H.; Wang, L.; Thomson, J.A.; Turng, L.-S.; Guan, G. Surface modification of polytetrafluoroethylene (PTFE) with a heparin-immobilized extracellular matrix (ECM) coating for small-diameter vascular grafts applications. Mater. Sci. Eng. C 2021, 128, 112301. [CrossRef]

67. Lee, S.-H.; Lee, C.-S.; Shin, D.-S.; Kim, B.-G.; Lee, Y.-S.; Kim, Y.-K. Micro protein patterning using a lift-off process with fluorocarbon thin film. Sens. Actuators B Chem. 2004, 99, 623-632. [CrossRef]

68. Ueno, H.; Inoue, M.; Okonogi, A.; Kotera, H.; Suzuki, T. Correlation between Cells-on-Chips materials and cell adhesion/proliferation focused on material's surface free energy. Colloids Surf. A Physicochem. Eng. Asp. 2019, 565, 188-194. [CrossRef]

69. Celik, N.; Sahin, F.; Ruzi, M.; Yay, M.; Unal, E.; Onses, M.S. Blood repellent superhydrophobic surfaces constructed from nanoparticle-free and biocompatible materials. Colloids Surf. B Biointerfaces 2021, 205, 111864. [CrossRef] [PubMed]

70. Yadhuraj, S.R.; Babu Gandla, S.; Omprakash, S.S.; Sudarshan, B.G.; Prasanna Kumar, S.C. Design and Development of Microchannel using PDMS for Biomedical Applications. Mater. Today Proc. 2018, 5, 21392-21397. [CrossRef]

71. Yadhuraj, S.R.; Babu Gandla, S.; Sudarshan, B.G.; Prasanna Kumar, S.C. Preparation and Study of PDMS Material. Mater. Today Proc. 2018, 5, 21406-21412. [CrossRef]

72. Liu, X.; Zhang, X.; Chen, Q.; Pan, Y.; Liu, C.; Shen, C. A simple superhydrophobic/superhydrophilic Janus-paper with enhanced biocompatibility by PDMS and candle soot coating for actuator. Chem. Eng. J. 2021, 406, 126532. [CrossRef]

73. Li, Z.; Liu, H.; Xu, X.; Ma, L.; Shang, S.; Song, Z. Surface modification of silicone elastomer with rosin acid-based quaternary ammonium salt for antimicrobial and biocompatible properties. Mater. Des. 2020, 189, 108493. [CrossRef]

74. Rogers, J.A.; Bao, Z.; Meier, M.; Dodabalapur, A.; Schueller, O.J.A.; Whitesides, G.M. Printing, molding, and near-field photolithographic methods for patterning organic lasers, smart pixels and simple circuits. Synth. Met. 2000, 115, 5-11. [CrossRef]

75. Han, M.A.; Jeon, J.H.; Shin, J.Y.; Kim, H.J.; Lee, J.S.; Seo, C.W.; Yun, Y.J.; Yoon, M.Y.; Kim, J.T.; Yang, Y.I.; et al. Intramyocardial delivery of human cardiac stem cell spheroids with enhanced cell engraftment ability and cardiomyogenic potential for myocardial infarct repair. J. Control Release 2021, 336, 499-509. [CrossRef] [PubMed]

76. Anada, T.; Fukuda, J.; Sai, Y.; Suzuki, O. An oxygen-permeable spheroid culture system for the prevention of central hypoxia and necrosis of spheroids. Biomaterials 2012, 33, 8430-8441. [CrossRef]

77. Nishimura, Y.; Wang, P.C. Possibility of culturing the early developing kidney cells by utilizing simulated microgravity environment. Biochem. Biophys. Res. Commun. 2021, 573, 9-12. [CrossRef] [PubMed]

78. Makohliso, S.A.; Giovangrandi, L.; Leonard, D.; Mathieu, H.J.; Ilegems, M.; Aebischer, P. Application of Teflon-AF ${ }^{\circledR}$ thin films for bio-patterning of neural cell adhesion. Biosens. Bioelectron. 1998, 13, 1227-1235. [CrossRef]

79. Hausmann, A.; Sanciolo, P.; Vasiljevic, T.; Weeks, M.; Schroën, K.; Gray, S.; Duke, M. Fouling of dairy components on hydrophobic polytetrafluoroethylene (PTFE) membranes for membrane distillation. J. Membr. Sci. 2013, 442, 149-159. [CrossRef]

80. Andreatta, F.; Lanzutti, A.; Aneggi, E.; Gagliardi, A.; Rondinella, A.; Simonato, M.; Fedrizzi, L. Degradation of PTFE non-stick coatings for application in the food service industry. Eng. Fail. Anal. 2020, 115, 104652. [CrossRef]

81. Zhao, Q. Effect of surface free energy of graded NI-P-PTFE coatings on bacterial adhesion. Surf. Coat. Technol. 2004, 185, 199-204. [CrossRef]

82. Zhao, Q.; Liu, Y.; Wang, C.; Wang, S.; Müller-Steinhagen, H. Effect of surface free energy on the adhesion of biofouling and crystalline fouling. Chem. Eng. Sci. 2005, 60, 4858-4865. [CrossRef] 
83. Krsmanovic, M.; Biswas, D.; Ali, H.; Kumar, A.; Ghosh, R.; Dickerson, A.K. Hydrodynamics and surface properties influence biofilm proliferation. Adv. Colloid Interface Sci. 2021, 288, 102336. [CrossRef] [PubMed]

84. Liu, Y.; Zhao, Q. Influence of surface energy of modified surfaces on bacterial adhesion. Biophys. Chem. 2005, 117, 39-45. [CrossRef] [PubMed]

85. Marrazzo, P.; Pizzuti, V.; Zia, S.; Sargenti, A.; Gazzola, D.; Roda, B.; Bonsi, L.; Alviano, F. Microfluidic Tools for Enhanced Characterization of Therapeutic Stem Cells and Prediction of Their Potential Antimicrobial Secretome. Antibiotics 2021, 10, 750. [CrossRef] [PubMed] 